\title{
Severe cutaneous reactions to captopril and enalapril; histological study and comparison with early mycosis fungoides
}

\author{
PN FURNESS, MJ GOODFIELD,* KA MACLENNAN, A STEVENS, LG MILLARD* \\ From the Departments of Pathology and *Dermatology, Nottingham University Hospital, Nottingham
}

SUMMARY A severe non-dose related skin eruption attributable to treatment with captopril wasic recently reported: this is distinct from the dose related rashes that have been widely described. ${ }^{10}$ Ultrastructural and immunohistochemical studies were carried out to determine in detail the histo-io logical features of this eruption: the histological appearances were similar to those found in earlyn mycosis fungoides, so that this disease was erroneously diagnosed in one case. Unlike most others complications resulting from treatment with Captopril, an indistinguishable rash can result from treatment with enalapril, a newer angiotensin converting enzyme inhibitor.

The introduction of captopril, the first drug to inhibit selectively the angiotensin converting enzyme, marked an important development in the treatment of hypertension and refractory cardiac failure. ${ }^{2}$ Unfortunately, its usefulness has been decreased by the development of numerous side effects, which commonly occur during treatment. These include renal impairment, neutropenia, agranulocytosis, hyperkalaemia, proteinuria, loss of taste and hypotension. ${ }^{3}$ One of the commonest side effects is an erythematous maculopapular skin rash, which occurs in up to $30 \%$ of patients treated with the drug ${ }^{4}$ and which seems to be related to dose; symptoms may disappear with continued treatment at a lower dose. Enalapril, a newer drug with a similar action but a different chemical structure, has been claimed to be free from these problems, ${ }^{5}$ though a single case report contests this. ${ }^{6}$

We reported a distinct more severe cutaneous reaction to captopril. ${ }^{1}$ Patients developed an urticated scaling erythematous rash, with some eczematous features. Considerable clinical oedema occurred, with some infiltration, particularly of more acute lesions. There was little clinical resemblance to any of the forms of cutaneous T cell lymphoma (CTCL). More chronic lesions became lichenified and hyperkeratotic on a background of erythroderma. The rash usually started on the hands and face and proceeded to generalised spread if treatment was not stopped (Fig. 1). Resolution was slow even after the drug was discontinued.

This rash seems to be allergic in nature as it is not

Accepted for publication 25 March 1986 dose related. The rash will not resolve unless the drug $\vec{\emptyset}$ is stopped completely and it will recur rapidly ono rechallenge. The histological features of all biopsy specimens examined to date have been similar; the pattern seen is not typical of a drug eruption. Indistinguishable clinical and histological features have been⿳亠 observed after treatment with nalapril.

\section{Material and methods}

Eight biopsy specimens from seven patients were identified retrospectively (Table 1 ). Paraffin sections $(5 \mu \mathrm{m})$ stained with haematoxylin and eosin were reviewed, but no further procedures were undertaken

Two cases were identified prospectively (Table 1) Skin biopsy specimens from these patients were sen? unfixed to the laboratory, divided, and treated as follows:

1 Tissue was fixed in formalin, processed, an 8 embedded routinely in paraffin. Sections $(5 \mu \mathrm{m})$ were cut and stained with haematoxylin and eosin. No

2 Tissue was fixed in $2.5 \%$ glutaraldehyde processed, and embedded in Epon. Ultrathin section of selected areas were cut, stained with uranyl acetatê and lead citrate, and viewed in a Jeol 1200 EX trans? mission electron microscope at $80 \mathrm{kv}$.

3 Tissue was snap frozen in freezing isopentane a $-150^{\circ} \mathrm{C}$ and sectioned at $5 \mu \mathrm{m}$ in a Slee cryostat. Sections were stained with a panel of monoclona antisera using an indirect immunoperoxidase tech nique (Table 2).

4 Tissue was fixed in formalin and embedded i⿱ 


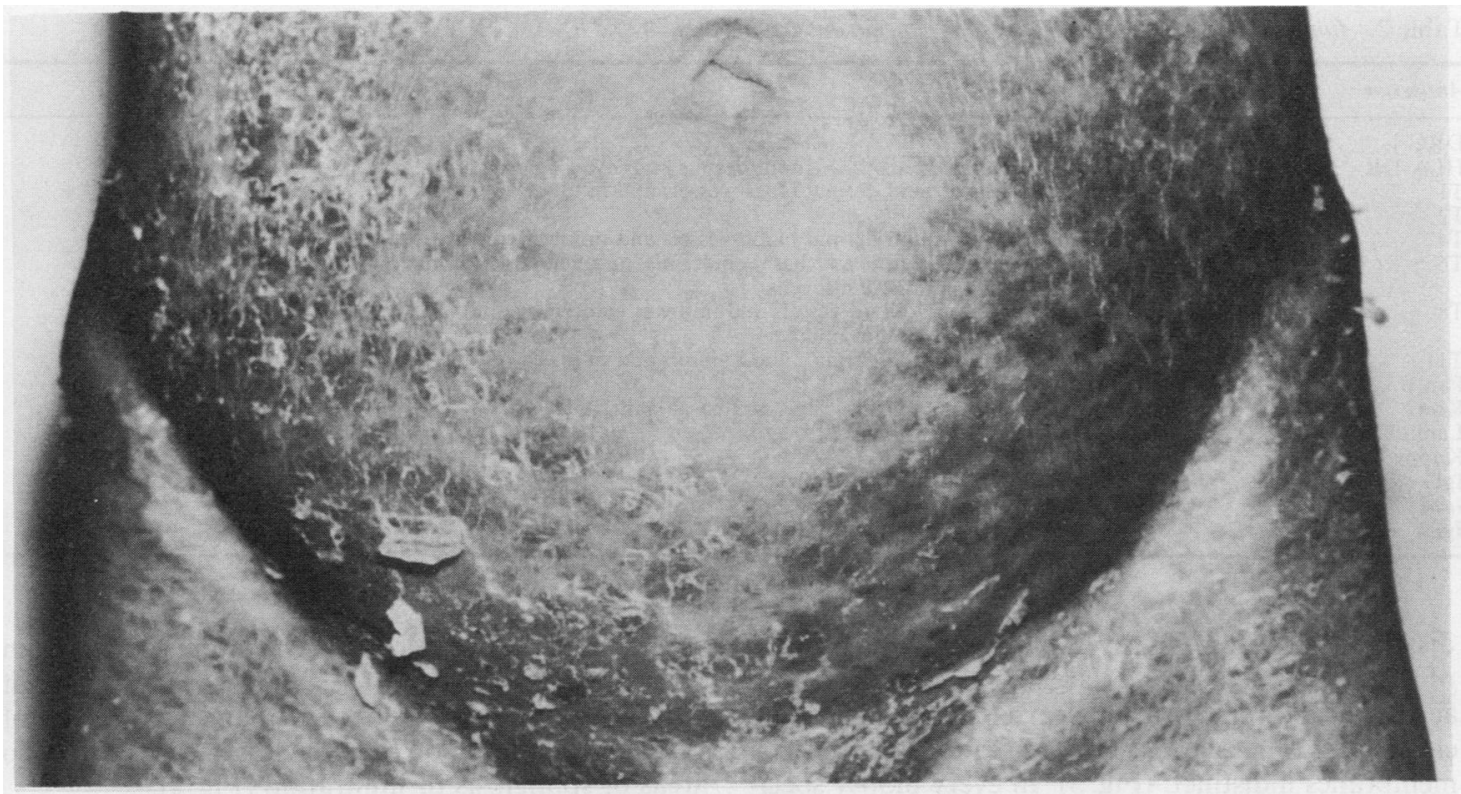

Fig. 1 Late stage of eruption induced by Captopril, showing generalised disease.

methyl methacrylate resin. Sections $(1 \mu \mathrm{m})$ were cut and stained with haematoxylin and eosin.

\section{Results}

We could detect no features to distinguish between the rashes caused by captopril and those caused by enalapril. We therefore treated this as a single series in the following analysis.

\section{LIGHT MICROSCOPY}

A consistent feature of all 10 biopsy specimens was an infiltrate of histiocytic cells and lymphocytes in the upper dermis. This was predominantly perivascular in

Table 1 Clinical material

\begin{tabular}{|c|c|c|c|c|}
\hline Case No & Diagnosis & Drug treatment & $\begin{array}{l}\text { Time before } \\
\text { rash developed }\end{array}$ & $\begin{array}{l}\text { Time of biopsy } \\
\text { after rash developed }\end{array}$ \\
\hline 1 & $\begin{array}{l}\text { Essential hypertension } \\
\quad \text { (creatinine } 95 \mu \mathrm{mol} / \mathrm{l})\end{array}$ & $\begin{array}{l}\text { Enalapril } \\
\quad 30 \mathrm{mg} \text { twice daily }\end{array}$ & 2 weeks & 2 weeks \\
\hline $2^{*}$ & $\begin{array}{l}\text { Cardiac failure, due to } \\
\text { rheumatic heart disease } \\
\text { (creatinine } 240 \mu \mathrm{mol} / \mathrm{l} \text { ) }\end{array}$ & $\begin{array}{l}\text { Captopril } \\
75 \mathrm{mg} \text { daily }\end{array}$ & 4 weeks & 1 week \\
\hline 3 & $\begin{array}{l}\text { Renovascular hypertension } \\
\text { (creatinine } 350 \mu \mathrm{mol} / \mathrm{l} \text { ) }\end{array}$ & $\begin{array}{l}\text { Enalapril } \\
\quad 30 \mathrm{mg} \text { twice daily }\end{array}$ & 4 weeks & 4 weeks \\
\hline $4^{*}$ & $\begin{array}{l}\text { Ischaemic cardiac failure } \\
\text { (creatinine } 130 \mu \mathrm{mol} / \mathrm{l} \text { ) }\end{array}$ & $\begin{array}{l}\text { Captopril } \\
75 \mathrm{mg} \text { daily }\end{array}$ & 3 weeks & 3 weeks \\
\hline $5^{*}$ & $\begin{array}{r}\text { Ischaemic cardiac failure } \\
\text { (creatinine } 150 \mu \mathrm{mol} / \mathrm{l} \text { ) }\end{array}$ & $\begin{array}{l}\text { Captopril } \\
75 \mathrm{mg} \text { daily }\end{array}$ & 6 weeks & 6 weeks \\
\hline $6 a^{*}$ & $\begin{array}{l}\text { Diabetic cardiomyopathy } \\
\text { (creatinine } 220 \mu \mathrm{mol} / \mathrm{l})\end{array}$ & $\begin{array}{l}\text { Captopril } \\
75 \mathrm{mg} \text { daily }\end{array}$ & 6 weeks & 2 weeks \\
\hline $6 b^{*}$ & Rechallenge of case $6 a$ & $\begin{array}{l}\text { Captopril } 12 \cdot 5 \mathrm{mg} \\
\text { as a single dose }\end{array}$ & & 3 days after challenge \\
\hline $7 \mathbf{a}$ & $\begin{array}{l}\text { Essential hypertension } \\
\text { atrial septal defect } \\
\text { (creatinine } 110 \mu \mathrm{mol} / \mathrm{l} \text { ) }\end{array}$ & $\begin{array}{l}\text { Captopril } \\
75 \mathrm{mg} \text { daily }\end{array}$ & 6 weeks & 2 weeks \\
\hline $7 b$ & Rechallenge of case $7 a$ & $\begin{array}{l}\text { Captopril } 12.5 \mathrm{mg} \\
\text { as a single dose }\end{array}$ & & 3 days after challenge \\
\hline 8 & $\begin{array}{r}\text { Ischaemic cardiac failure } \\
\text { (creatinine } 211 \mu \mathrm{mol} / \mathrm{l} \text { ) }\end{array}$ & $\begin{array}{l}\text { Captopril } \\
75 \mathrm{mg} \text { daily }\end{array}$ & 3 weeks & 4 weeks \\
\hline
\end{tabular}

Biopsy specimens from cases $7 \mathrm{~b}$ and 8 were identified prospectively.

*Indicates cases previously reported. 
Table 2. Immunoperoxidase studies on biopsy specimens from cases $7 b$ and 8

\begin{tabular}{ll}
\hline Antiserum & Results \\
\hline DRC 1 & Negative \\
HLA-DR & Numerous positive cells throughout dermis and lower epidermis \\
T1 & Numerous cells around dermal blood vessels and in lower epidermis \\
T2 & Negative \\
T4 & Numerous cells around dermal blood vessels and in lower epidermis; similar to T1 \\
T6 & Cells in superficial dermis and basal epidermis, in much larger numbers than the normal \\
T8 & distribution of Langerhans' cells \\
T11 & Cells around dermal blood vessels and in lower epidermis; similar distribution to T1 and \\
Pan B & T4, but in much smaller numbers \\
Ki-67 & Numerous cells around dermal blood vessels and in lower epidermis; similar to T1 \\
Lambda & Negative \\
Kappa & Positive cells in superficial dermis and basal epidermis \\
IgG & Negative \\
IgM & Negative \\
IgD & Negative \\
\hline
\end{tabular}

distribution (Fig. 2). In seven biopsy specimens many of the lymphocytes had large nuclei up to $10 \mu \mathrm{m}$ across with cerebriform nuclear contours and dense chromatin. The cytoplasm was scanty and the cell membranes indistinct. (Fig. 3). In every biopsy specimen but one (case 2) mononuclear cells were also seen infiltrating the epidermis; in several cases these were recognisable as the atypical lymphoid cells described above (Fig. 4). Numerous mitoses were seen in the dermal infiltrate and occasionally in the epidermis. Focal spongiosis was noted in every case but one (case 3 ), usually in areas with atypical lymphocytes in the epidermis. Other features present in the specimens in varying degree included irregular acanthosis (six of $\stackrel{ }{\mathrm{S}}$ 10), hyperkeratosis (eight of 10), and focal areas of parakeratosis (nine of 10), which were not related to areas of spongiosis or infiltration (Fig. 2).

None of these features is specific, but the appearances are not those commonly seen in drug eruptions. $\varnothing$ They closely resemble the early stages of cutaneous $T$ ? cell lymphoma (CTCL); indeed, in case 1 an experienced pathologist had suggested that the diagnosis of mycosis fungoides should be considered, despite being aware of the patient's drug history.

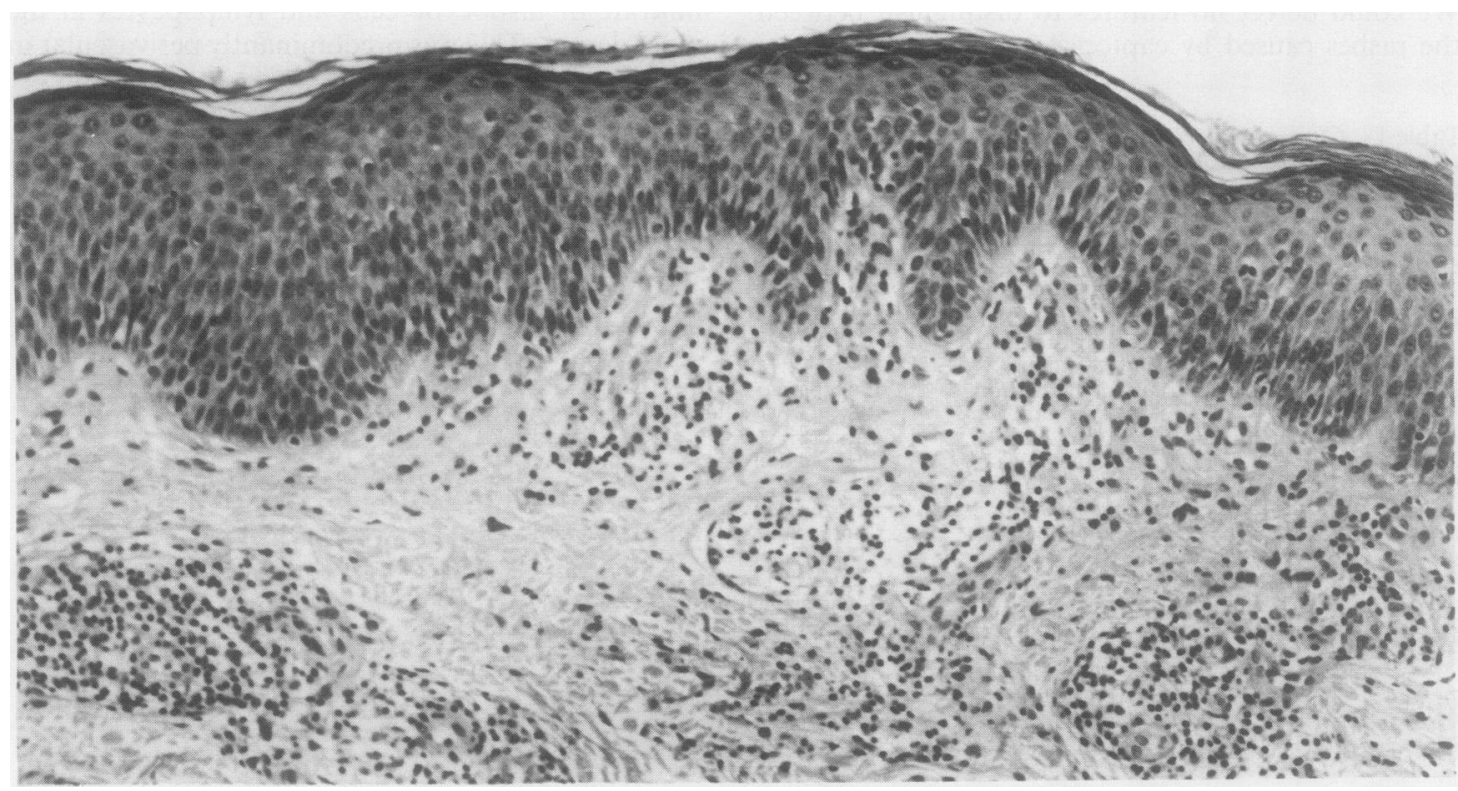

Fig. 2 Biopsy specimen of eruption induced by Captopril, showing infiltrate of mononuclear cells predominantly around superficial dermal blood vessels invading epidermis. Note also parakeratosis. (Haematoxylin and eosin.) $\times 144$. 


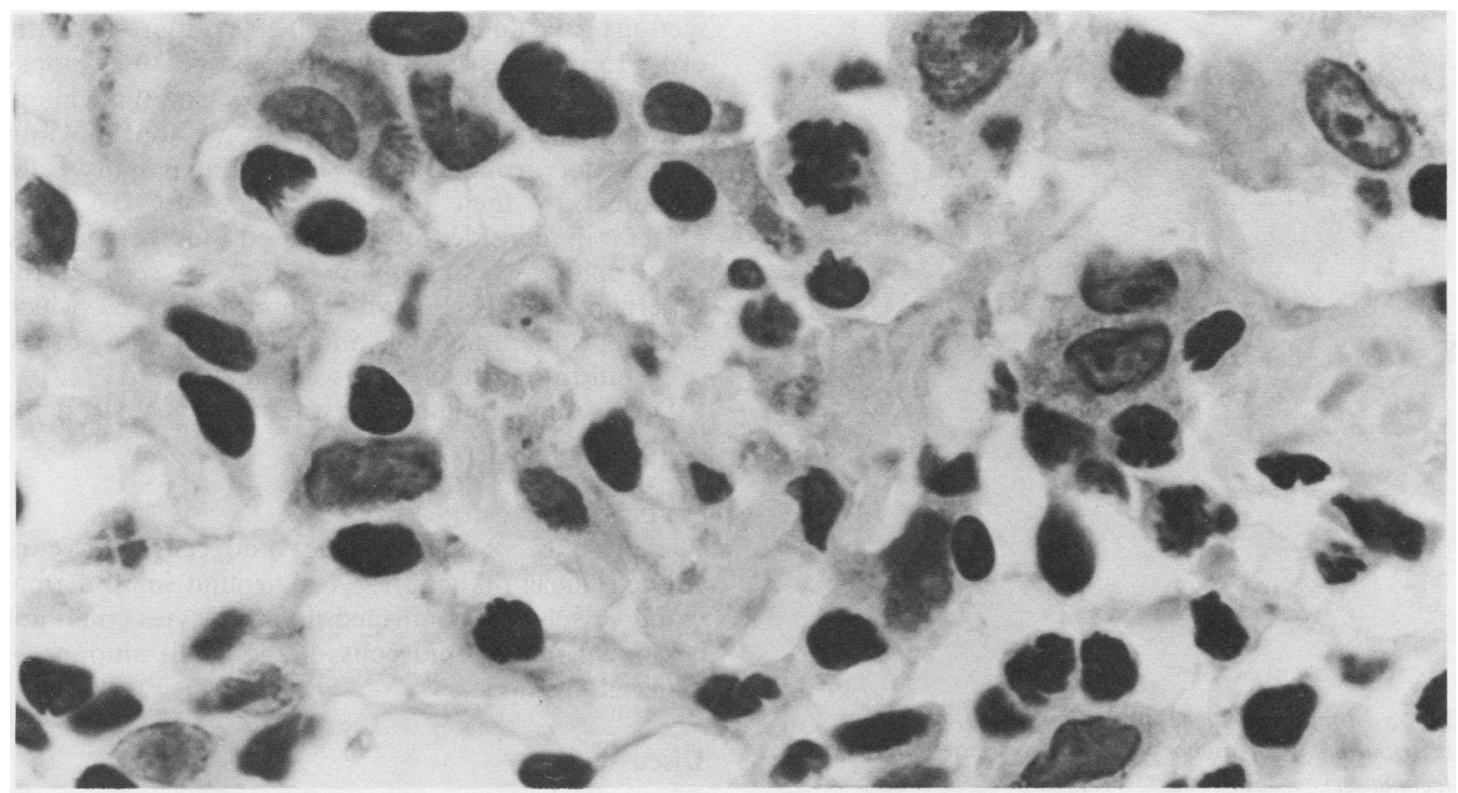

Fig. 3 Atypical lymphocytes with cerebriform nuclear contours around dermal blood vessel. (1 $\mu$ m resin section, haematoxylin and eosin.) $\times 1350$.

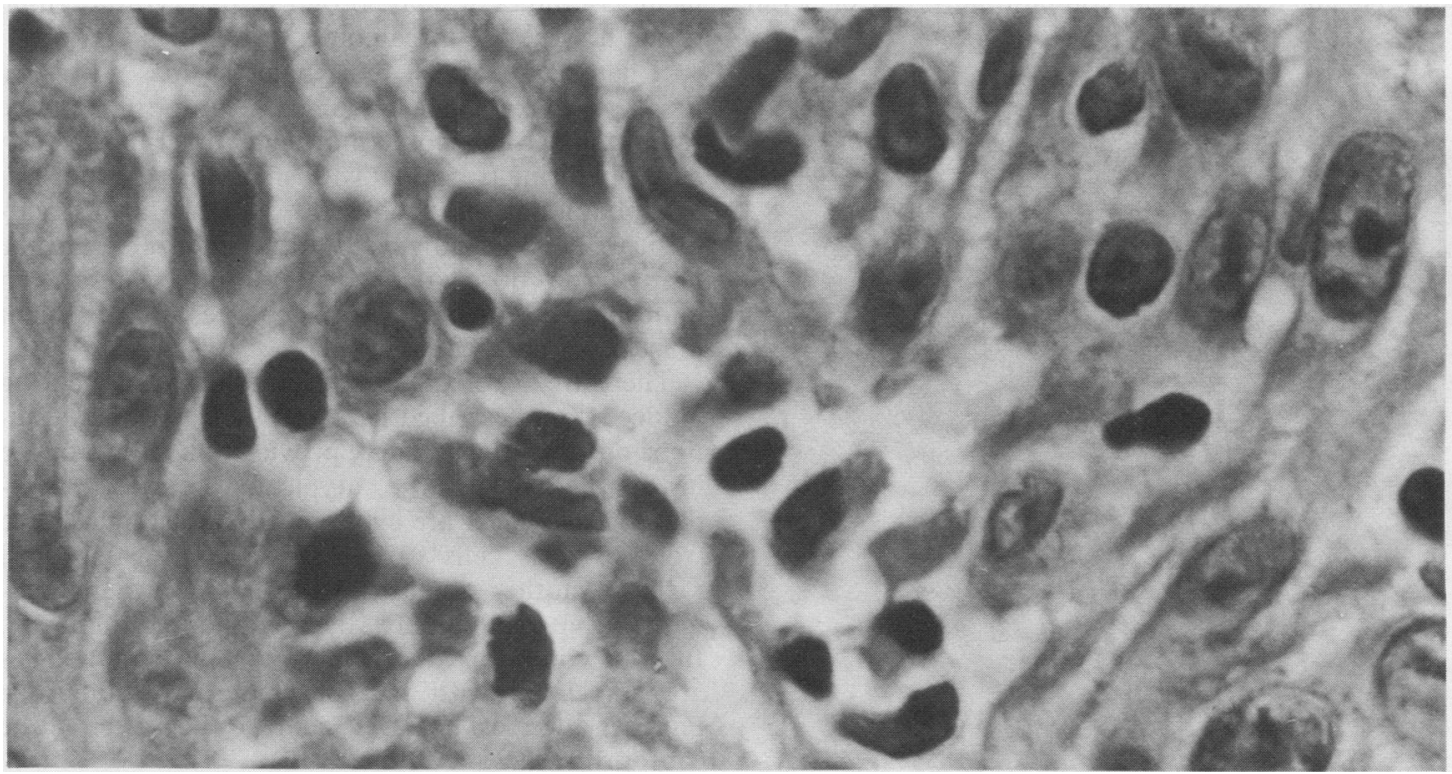

Fig. 4 Mononuclear cells, including cells with irregular nuclei, within epidermis, with associated spongiosis. (Haematoxylin and eosin.) $\times 1440$. 


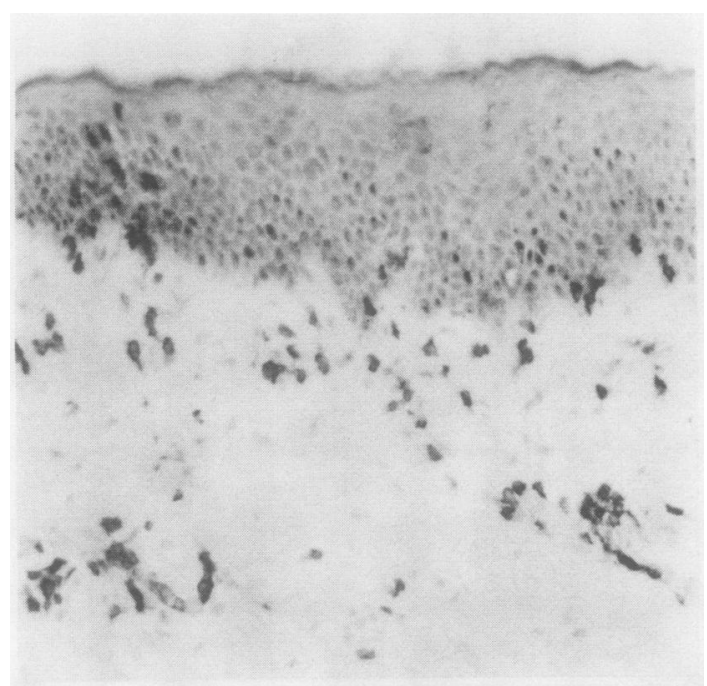

Fig. 5 Immunohistochemical stain for $T 1$ indicating distribution of T lymphocytes. (Indirect immunoperoxidase technique.) $\times 360$.

\section{IMMUNOCYTOCHEMISTRY}

Table 2 illustrates the results of the immunocytochemical studies. They indicate that the lymphoid cells in dermis and epidermis were $T$ lymphocytes (Fig. 5) and that most were $T$ helper cells. $T$ suppressor cells were present in much smaller numbers, and B lymphocytes were absent. Counting T4 and $\mathrm{T} 8$ positive cells in comparable areas of serial

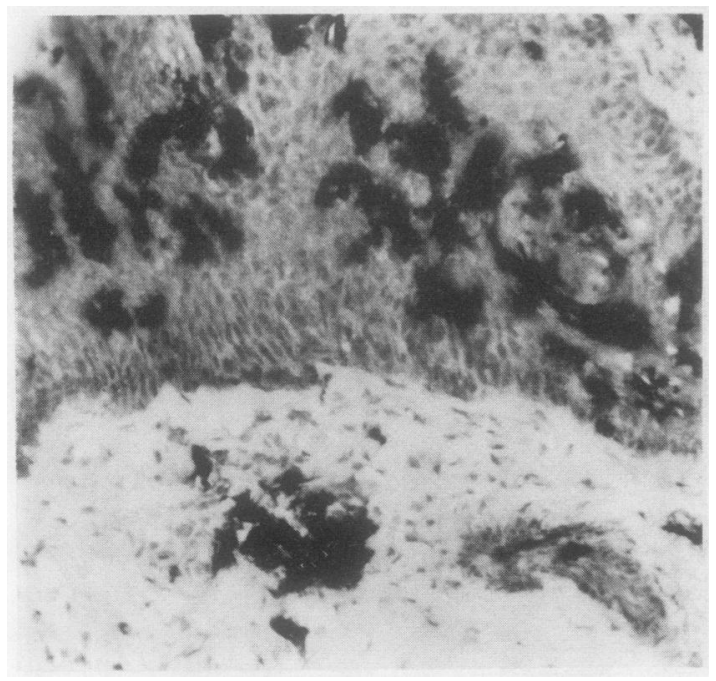

Fig. 6 Immunohistochemical stain for T6 indicating distribution of Langerhans' cells. (Indirect immunoperoxidase technique.) $\times 360$. sections gave an approximate helper:suppressor ratio $\stackrel{0}{\overrightarrow{5}}$ of 85:15 in biopsy specimen $7 \mathrm{~b}$, and 80:20 in biopsy 으 specimen 8 . Macrophages were present throughout $\vec{\Rightarrow}$ the dermis and lower epidermis, without obvious $\stackrel{5}{+}$ aggregation around blood vessels. Langerhans' cells, 을 identified by their positive staining for $T 6$, were 흠 present in considerably increased numbers in the $\frac{\bar{\omega}}{7}$ basal epidermis, and many were also seen in the $\stackrel{\mathbb{Q}}{\varrho}$ superficial dermis (Fig. 6). Staining for $\mathrm{Ki}-67$, which detects proliferating cells, indicated that many of the cells infiltrating the dermis were in cycle.

Surface immunoglobulin was not detected on the $\overrightarrow{\vec{\omega}}$ lymphocytes.

\section{ELECTRON MICROSCOPY}

The presence of macrophages and cells with con voluted nuclei (T lymphocytes) around small dermal blood vessels was confirmed. Lymphocytes could not N be shown in the epidermis in the small amount of 을 material available.

\section{Discussion}

Recognition of this complication of treatment with $\vec{\bullet}$ captopril and enalapril is important for both clinician $\infty$ and histopathologist. Skin rashes are a well recognised complication of treatment with captopril, but they are usually trivial and will usually resolve after a reduction in dosage, ${ }^{2}$ or even if the original dose is maintained. ${ }^{7}$ The rash described here is more serious; $\frac{\circ}{\Phi}$ it will not resolve unless the drug is stopped. If treatment continues it may progress to erythrodermia, which may be life threatening.

It has been claimed that enalapril does not cause the dose dependent rash seen with captopril, ${ }^{5}$ but we found that this dose independent eruption can $\bar{P}$ develop during treatment with either drug. It thus fol- :lows that a patient who develops a rash during treat -3 . ment with enalapril is likely to be suffering from the more serious dose independent eruption. A reduction 3 in dosage will therefore be inadequate, and treatment $\mathrm{O}$ must be stopped completely.

There are histological similarities between the drug $\frac{\vec{O}}{0}$ induced rash described here and the early manifestations of CTCL, which may provide difficulties for the $\stackrel{\sim}{\sigma}$ histopathologist. Large, atypical, cerebriform lym- N phoid cells, which are cytologically indistinguishable N from mycosis cells ${ }^{8}$ are easily found in captopril $\underset{\sigma}{\sigma}$ rashes. Another similarity with CTCL is the epidermotropism exhibited by the lymphocytic infiltrate. In both conditions the epidermotropic lymphocytes $\mathscr{尺}$ are associated with foci of epidermal spongiosis; Pautrier abcesses, however, have not been seen in the captopril rashes.

In contrast to typical CTCL, the mononuclear cell $\underset{\mathbb{D}}{\stackrel{O}{\alpha}}$ infiltrate associated with these skin rashes is not band 
like but shows a perivascular orientation. The number of atypical lymphoid cells is rather less than might be anticipated in CTCL, but this distinction is not absolute, because in foci of some biopsy specimens of captopril rashes up to one third of the mononuclear cells present have cerebriform nuclei.

The immunohistochemical studies show striking similarities between CTCL and the captopril rash. The two conditions appear indistinguishable immunohistologically. The absence of B cells, the predominance of $T 4$ positive $T$ helper cells, and the positive staining of many of the cells by HLA-DR (indicating activation) are typical of CTCL. Staining with OKT6 shows increased numbers of epidermal and dermal Langerhans' cells, a finding almost universally present in CTCL. ${ }^{910}$ Identification of proliferating cells by $\mathrm{Ki}-67$ shows considerable numbers of cells in cycle, though perhaps fewer than might be expected in CTCL.

The features of this rash unequivocally indicate an immunological pathogenesis. The theories suggested for the pathogenesis of the dose related captopril rashes, including the influence of the sulphidryl group, ${ }^{25}$ binding of heavy metals, ${ }^{11}$ and the potentiation of kinin mediated cutaneous reactions ${ }^{12}$ cannot be invoked here.

In normal skin the function of the Langerhans' cells is believed to be that of "trapping" and concentrating foreign antigens. ${ }^{13}$ These cells then "present" the antigen, together with their surface class II histocompatibility antigens, to appropriate $\mathrm{T}$ lymphocytes. The resultant activated $T$ helper lymphocytes are able to stimulate B lymphocytes to produce a specific antibody response, or to stimulate other subsets of $T$ lymphocytes to produce a cell mediated immune response. This system seems to play a part in both CTCL and the captopril skin rash. In CTCL abnormalities are believed to arise because of the presence of neoplastic T4 positive lymphocytes, which tend to migrate to the skin and induce the proliferation and accumulation of Langerhans' cells. ${ }^{9}$ Alternative or additional theories, however, have been suggested, particularly in relation to the early stages of CTCL. Initial stimulation of Langerhans' cells by persistence of antigen in the dermis has been proposed. ${ }^{14}$ Viral infection has been suggested as a cause, ${ }^{15}$ and retrovirus like particles have been identified in Langerhans' cells. ${ }^{16}$ We believe that the captopril skin rash is also caused by abnormal stimulation of Langerhans' cells and hence of T helper cells. Persistence or accumulation of captopril in the skin, in a patient who is becoming sensitised to the drug, could produce excessive stimulation of the dermal antigen handling system. Such stimulation would then cause the observed excess of Langerhans' cells and T helper cells. Both CTCL and the captopril rash thus represent a parody of a normal immunological process.

In practical terms, the histopathologist should be aware that large atypical lymphocytes showing migration into the epidermis can result from a drug reaction and do not necessarily indicate a malignant or premalignant condition.

\section{References}

'Goodfield MJ. Millard LG. Severe cutaneous reaction to Captopril. Br Med J 1985;290:1111.

${ }^{2}$ Hodsman GP. Robertson JIS. Captopril; five years on. Br Med J 1983:287:851-2.

${ }^{3}$ ABPI. Data sheet compendium. London: Datapharm Publications, 1984-5:1351-4.

${ }^{4}$ Luderer JR. Lookingbill DP. Schenck DW. Demers LM, Cohen C. Hayes AH. Captopril-induced skin eruptions. J Clin Pharmacol 1982:22:151-9.

${ }^{5}$ Gavras I. Gavras H. Captopril and Enalapril. Ann Intern Med 1983:98:556-7.

${ }^{6}$ Barnes JN. Davies ES. Gent CB. Rash. eosinophilia and hyperkalaemia associated with Enalapril. Lancet 1983;ii:41.

' Luderer JR. Lookingbill DP. Schenck DW. Demers LM. Hayes AH. Captopril-induced skin eruptions. Clin Res 1980:28:589A.

${ }^{8}$ Lutzner MA. Hobb JW. Horvath P. Ultrastructure of abnormal cells in Sézary syndrome. mycosis fungoides and parapsoriasis en plaque. Arch Dermatol 1971:103:375-86.

${ }^{9}$ Chu A. Berger CL. Lynfield Y. Estesse I. Edelson RL. Pathogenesis of cutaneous T cell lymphoma. In: Goos M. Christophers E, eds. Limphoproliferative disorders of the skin. Berlin: Springer Verlag. 1982:57-64.

${ }^{10}$ Thomas JA. Janossy G. Phenotypic analysis of cells in cutaneous lymphoma: an immunohistologic study. In: Goos M. Christophers E. eds. Limphoproliferative disorders of the skin. Berlin: Springer Verlag, 1982:128-36.

${ }^{11}$ Brugeggemeyer CD. Ramirez G. Onycholysis associated with Captopril. Lancet 1984;:1352.

${ }^{12}$ Wilkin JW. Hammond JJ, Kirkendall WM. The Captopril-induced eruption. Arch Dermatol 1980:116:902-5.

${ }^{13}$ Roilt IM. Essential immunology. 5th ed. Oxford: Blackwell Scientific Publications, 1984:65-77.

${ }^{14}$ Tan RS-H. Butterworth CM, McLaughlin H, Malka S, Samman PD. Mycosis Fungoides-a disease of antigen persistence. Br J Dermatol 1974:91:607-16.

${ }^{15}$ MacKie RM. Initial event in mycosis fungoides of the skin is viral infection of epidermis Langerhans' cells. Lancet 1981:ii:283-5.

${ }^{16}$ Slater DN, Rooney N, Bleehen S, Hamed A. The lymph node in mycosis fungoides: a light and electron microscopy and immunohistological study supporting the Langerhans. cell-retrovirus hypothesis. Histopathology 1985;9:587-621.

Requests for reprints to: Dr PN Furness, Department of Pathology, University Hospital, Queen's Medical Centre, Nottingham NG7 2UH, England. 